\title{
The Long Resistance
}

\section{TOMIKO BROWN-NAGIN}

\section{Introduction}

We are living in an age of political turbulence, social division, and resistance. The resistance that formed in reaction to the election of Donald Trump styles itself a force to defend constitutional rights, democratic norms, and the rule of law in the United States. Perhaps the New Republic best explained its advent: the Resistance had been born of partisan - that is, Democratic - fury after "liberalism had been dealt its most stunning and consequential defeat in American history." "For the first time in decades, liberalism has been infused with a sense of energy and purpose," with millions of people devoted to a singular cause: resisting Trump. ${ }^{2}$

I agree that the millions-strong nationwide protests, the array of state and locally based efforts to win back electoral power-and the subject of the furor, Donald Trump - are remarkable in many ways.

Nevertheless, it seems to me that we-as citizens and as scholarsought to contextualize and historicize this moment with a view toward assessing where it stands in the long arc of American history. What is happening here?

Many writers have turned to the Tea Party to describe this moment. ${ }^{3}$ As I will explain momentarily, I find this analogy curious and mostly inapt.

1. Jeet Heer, "The Path of Most Resistance," New Republic, May 11, 2017. https:// newrepublic.com/article/142425/path-resistance-promise-perils-democrats-fight-against-trump (accessed July 18, 2018).

2. Ibid.

3. See, for example, Molly Ball, "Is the Anti-Trump 'Resistance' the New Tea Party?" The Atlantic, February 9, 2017. https://www.theatlantic.com/politics/archive/2017/02/resistance-tea-party/516105/ (accessed July 18, 2018); contra Paul Rosenberg, "Stronger than

Tomiko Brown-Nagin is Dean of the Radcliffe Institute for Advanced Study, Daniel P.S. Paul Professor of Constitutional Law, and Professor of History at Harvard University. These remarks were delivered as the 2017 American Society of Legal History plenary lecture. 
I see the current Resistance in relation to activism that stretches back to the anti-World Trade Organization (WTO) protests, ${ }^{4}$ Occupy Wall Street, ${ }^{5}$ the fight for a $\$ 15$ minimum wage, ${ }^{6}$ the Movement for Black Lives, ${ }^{7}$ and the scattered protests against the Affordable Care Act (ACA) that preceded the Tea Party. ${ }^{8}$

All these recent protests were reactions, in part, to structural economic and political inequalities: disparities linked to the global flow of trade and people. Joseph Stiglitz, the Nobel Prize-winning economist, warned us that the capture and corruption of the political system by moneyed interests could create profound instability. ${ }^{9}$ That movement has arrived: backlash against structural economic and political inequality is the tie that binds contemporary movements on the Right and the Left.

What is more, the recent movements are connected conceptually to the unfinished business of the mid-twentieth-century resistance movements for labor, civil and women's rights - movements that, in turn, tackled unresolved eighteenth- and nineteenth-century conflicts over social and economic inequality - the subjects of the abolitionist, suffrage, and progressive movements. Altogether, these movements struggled to uproot Founding era commitments to property rights over human rights, while

Tea: the anti-Trump resistance is much bigger than the Tea Party-and it has to be," Salon, March 11, 2017. https://www.salon.com/2017/03/11/stronger-than-tea-the-anti-trump-resistance-is-much-bigger-than-the-tea-party-and-it-has-to-be/ (accessed July 18, 2018).

4. On the World Trade Organization protests of 1999 in Seattle, Washington, see Lesley J. Wood, introduction to Direct Action, Deliberation and Diffusion (New York: Cambridge University Press, 2012).

5. On Occupy Wall Street, which began in 2011 in New York City, see Matthew Bolton, Emily Welty, Meghana Nayak, and Christopher Malone, Occupying Political Science: The Occupy Wall Street Movement from New York to the World (New York: Palgrave Macmillan, 2013), 1-8.

6. See "About Us," Fight for $\$ 15$, n.d., https://fightfor15.org/about-us/ (accessed November 20, 2017); also see Annaelise Orleck, "We are All Fast Food Workers Now": The Global Uprising against Poverty (Boston: Beacon, 2018); and Steven Ashby, "Assessing the Fight for Fifteen Movement from Chicago," Labor Studies Journal 42 (2017): 366-86.

7. See "About Us," The Movement for Black Lives, n.d. https://policy.m4bl.org/about/ (accessed November 20, 2017). For perspectives on the origins and context in which the movement developed, see Keeanga-Yamahatta Taylor, From \#BlackLivesMatter to Black Liberation (Chicago: Haymarket, 2016); and Christopher LeBron, The Making of Black Lives Matter: A Brief History of an Idea (New York: Oxford University Press, 2017).

8. See Theda Skocpol and Vanessa Williamson, The Tea Party Movement and The Remaking of Republican Conservatism (New York: Oxford University Press, 2016), 3-12, 56, 160, 162-63; and Janet L. Dolgin and Katherine R. Dietrich, "Social and Legal Debate about the Affordable Care Act," UMKC Law Review 80 (2011): 83-84.

9. Joseph E. Stiglitz, The Price of Inequality (New York: W. W. Norton \& Co., 2012). 

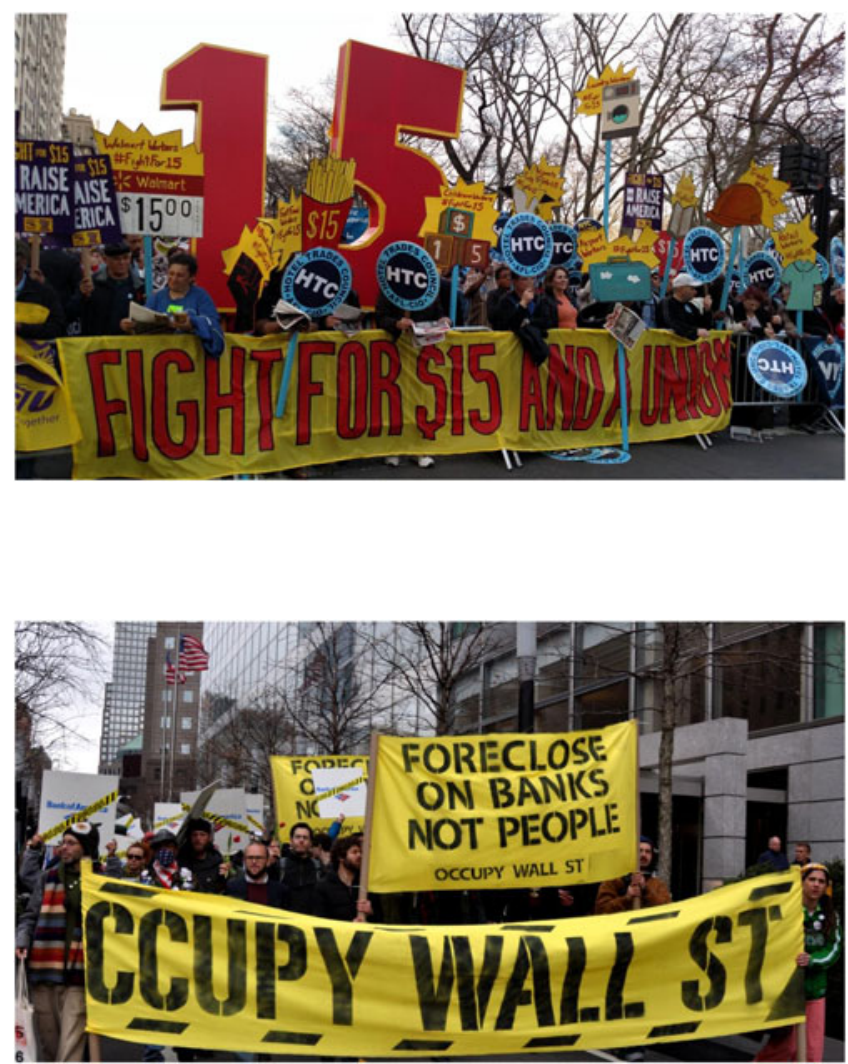

affirming Founding and Reconstruction era promises of liberty and equality. ${ }^{10}$ Therefore, far from being only or even mostly about the present occupant of the White House, the current Resistance reflects a long and contentious struggle over the nature of the American social contract itself. $^{11}$ That, I suggest, is what is happening here.

10. See Tomiko Brown-Nagin, "The Constitution, the Law and Social Change: Mapping Pathways of Influence," in Cambridge Companion to the Constitution, eds. John Compton and Karen Orren (New York: Cambridge University Press, 2018); Alfred L. Brophy, "The Civil Rights Act of 1964 and the Fulcrum of Property Rights," Alabama Civil Rights \& Civil Liberties Law Review 6 (2014): 75-76; and Paul J. Larkin, Jr., "The Original Understanding of 'Property' in the Constitution," Marquette Law Review 100 (2016): 6-11.

11. See Bruce Ackerman, We The People, Volume 3 (Cambridge: Belknap Press, 2014), 7; and Vine Deloria, Jr., "Minorities and the Social Contract," Georgia Law Review 20 (1986): 918-21. 


\section{Three Observations about Twentieth-Century Social Movements}

Having offered a big picture analysis of the relationship between the present and the past, I now want to engage in a more granular analysis, in hopes of illustrating continuity and change in the ways in which struggle over the social contract has found expression over time. Analyzing these movements from within, or bottom up, as well as top down, or from the perspective of external phenomena and elite institutions, I offer observations about three inter-related issues: (1) how progressive social movements historically have deployed rights talk to press agendas for structural social and economic change - not merely to overthrow a political figure; (2) how these movements have engaged political parties and electoral politics; and (3) how historical memory of these eras fails to sufficiently reckon with counter-movements on the Right or with political mobilizations on the Left of the working class and poor, particularly people of color. Both mobilized groups are highly relevant to our world today.

\section{Rights Talk}

First, let us consider protest movements and rights talk. One of major goals of the current Resistance, say various mission statements, is affirmation of the rule of law. ${ }^{12}$ It turns out that protest movements have long deployed the rhetoric of democratic constitutionalism to frame disputes and move forward their agendas, but often in a different voice than today.

Mobilized groups invoke a thick conception of law-not only the Constitution - the "paramount law," to quote Chief Justice John Marshall13 _ but the aspirational language of the Declaration of Independence and the Preamble to the Constitution; loose interpretations of case law, and popular understandings of what law should be.

Movements invoke rights talk in four major ways: (1) to make legal claims, (2) for moral suasion, (3) for cultural identification, and (4) for political mobilization. Which is to say: social movements deploy legal concepts strategically, and much more supplely than is possible in formal settings where judges are the primary interpreters of the law. ${ }^{14}$

12. See “Our Mission," The Resistance Party, 2017. https://www.theresistanceparty.org/ (accessed January 7, 2018); and "The Trump Threat to the Rule of Law and the Constitution," Niksaken Center, February 3, 2017. https://niskanencenter.org/blog/trumpthreat-rule-law-constitution/ (accessed January 7, 2018).

13. Marbury v. Madison, 5 U.S. 137, 177.

14. Tomiko Brown-Nagin, "The Civil Rights Canon: Above and Below," The Yale Law Journal 123 (2014): 2698-2739. 


\section{The Long Civil Rights Movement}

The twentieth-century civil rights movement constitutes perhaps the best example of a social reform campaign's appropriation of constitutional and legal constructs in these ways. The movement - composed of many different organizations - deployed law in ways befitting each group.

The National Association for the Advancement of Colored People (NAACP) Legal Defense Fund (Inc. Fund), led by a self-consciously professional cadre of lawyers and top-down leaders, turned to text- and history-based constitutional arguments to claim rights.

The Southern Christian Leadership Conference (SCLC) spearheaded by ministers, deployed aspirational legal rhetoric for moral suasion.

The Student Non-Violent Coordinating Committee (SNCC), anchored by radical student activists and supported by "movement lawyers" inclined toward collaborative lawyering styles, referenced legal precepts for cultural critique and political mobilization.

All together, these institutions - working in a dynamic geopolitical environment $\_$pushed the public, the courts, and Congress to dismantle Jim Crow.

\section{Law for Claims-Making in the Black Freedom Struggle}

The campaign to end Jim Crow in schools is the archetypical example of legal claims-making by a social movement-one that also highlights enduring conflict within and outside of movements over the priority to assign to structural economic inequality.

Thurgood Marshall served as the chief attorney translating the movement's grievances into legal claims, and he jealously guarded his strategy in the face of critics who preferred a different one. ${ }^{15}$

Those critics included A. Philip Randolph, the labor leader. Randolph acknowledged that the Constitution's open-ended language could support many interpretations of the law, but he worried that federal courts would misinterpret, water down, or simply reject legitimate claims. ${ }^{16}$ Randolph urged black and white workers to unite, form unions, and struggle as a collective for higher wages and better working conditions. ${ }^{17}$

15. Brown-Nagin, Courage to Dissent (New York: Oxford University Press, 2012), 4.

16. See A. Philip Randolph and Chandler Owen, "A Socialist Critique in The Messenger," in Black Protest Thought in the Twentieth Century (Indianapolis: Bobbs-Merrill, 1971), 84, 86-87, 88.

17. See David Welky, Marching Across the Color Line: A. Philip Randolph and Civil Rights in the WWII Era (New York: Oxford University Press, 2013). 


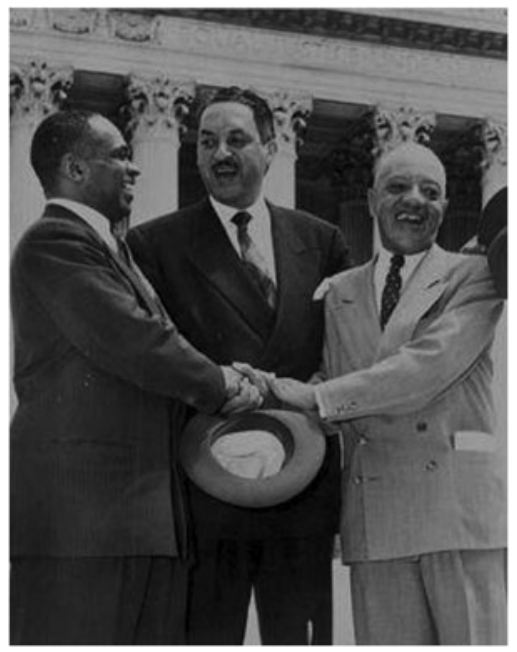

However, Marshall insisted "the way to change America was through the courts," 18 and he laid claim to the Constitution as amended during Reconstruction: the period that W.E.B. DuBois called African-Americans" "brief moment in the sun." 19 And, as a result of external factors such as the war against fascism, juxtaposed to Jim Crow, which exposed American hypocrisy; the activism of black veterans; and lynchings that dramatized the depravity of white supremacy-Marshall and his team prevailed in Brown $v$ Board of Education. ${ }^{20}$

The Inc. Fund largely left it to other institutions, including organized labor and federal agencies, to pursue a labor-civil rights agenda, as scholars such as Sophia Lee and Nancy MacLean have demonstrated. ${ }^{21}$

18. Brown-Nagin, Courage to Dissent, 4.

19. W.E.B. DuBois, Black Reconstruction in America: Toward a History of the Part Which Black Folk Played in the Attempt to Reconstruct Democracy in America, 18601880 (Piscataway: Transaction Publishers, 2013), 26.

20. See Mary L. Dudziak, Cold War Civil Rights: Race and the Image of American Democracy (Princeton: Princeton University Press, 2011).

21. See Nancy MacLean, Freedom is Not Enough: The Opening of the American Workforce (New York and Cambridge: Russell Sage Foundation, 2006); Sophia Lee, "Hot Spots in a Cold War: The NAACP's Post-War Labor Constitutionalism, 19481964," Law and History Review 26 (2008): 327-77; and Sophia Lee, The Workplace Constitution: From the New Deal to the New Right (New York: Cambridge University Press, 2014). 


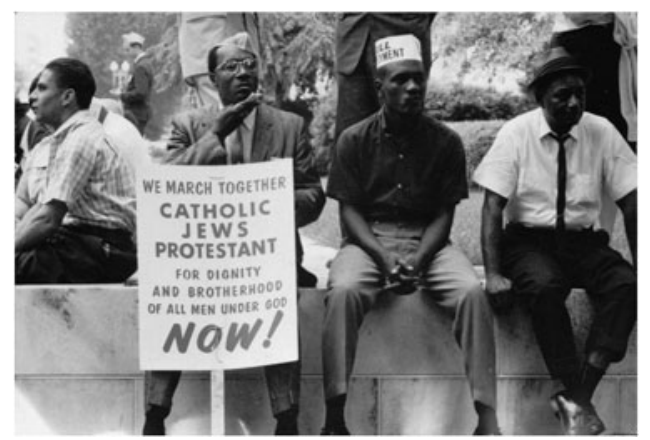

\section{Law as Moral Resource}

Dr. Martin Luther King - the leader-agent of campaigns against segregation in Montgomery, Birmingham, Selma, and Chicago - deployed rights talk for moral suasion-a use that allows the layperson a great deal of interpretative space. ${ }^{22}$ Dr. King frequently invoked constitutional concepts such as "liberty, equality, and citizenship," the idea of the rule of law, the words of the Declaration of Independence and Brown $v$ Board of Education, to argue that racial discrimination violated the laws of both God and humanity. ${ }^{23}$

\section{Montgomery}

Dr. King brilliantly articulated these views during the famed Montgomery Bus Boycott, when he told an audience at the Holt Street Baptist Church that the rights belonging to citizens in a constitutional democracy justified the boycott. "We are here, Dr. King said, because first and foremost-we are American citizens, and we are determined to apply our citizenship - to the fullness of its means. We are here... because of our love for democracy, because of our deep-seated belief that democracy transformed from thin paper (that is, the Constitution and laws) to thick action is the greatest form of government on earth." 24

Dr. King also invoked Brown, decided a year before the boycott, to justify the protest, saying: "If we are wrong, the Supreme Court of this nation

22. See Brown-Nagin, "The Constitution, the Law and Social Change."

23. Brown-Nagin, "The Civil Rights Canon," 2705.

24. Martin Luther King, Jr., "MIA Mass Meeting at Holt Street Baptist Church," speech, December 5, 1955, Montgomery, transcript. https:/swap.stanford.edu/20141218221308/http:// mlk-kpp01.stanford.edu/kingweb/publications/papers/vol3/551205.004-MIA_Mass_Meeting_ at_Holt_Street_Baptist_Church.htm (accessed July 18, 2018). 


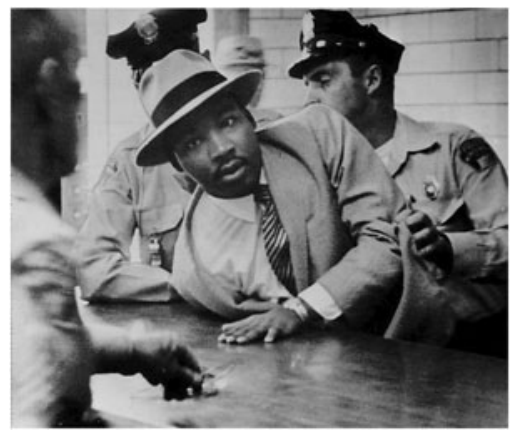

is wrong. If we are wrong, the Constitution of the United States is wrong. If we are wrong, God Almighty is wrong." 25

In Dr. King's telling, one violation of the equal protection clause necessarily gave rise to another, a claim that constitutional scholars of the era found debatable, ${ }^{26}$ but Dr. King was not counting on law professors to lead the movement. His rhetoric - including the loose reading of Brownworked for a religious audience of non-lawyers ${ }^{27} \mathrm{He}$ inspired the movement's proponents and put opponents on the defensive.

It is by articulating a vision of equality "deeply rooted in the American Dream," as Dr. King explained at the March on Washington for Jobs and Freedom in $1963^{28}$ - and by coupling public addresses with nonviolent protests in the face of violent white resistance - including beatings, bombings, and murders, including of children - that Dr. King and the communities he mobilized laid the groundwork for enactment of the omnibus Civil Rights Act of $1964^{29}$ and the Voting Rights Act of 1965, called the nation's "finest hour." 30

25. Ibid.

26. See generally, Alexander Bickel, "The Original Understanding and the Segregation Decision," 81 Va. L. Rev. 947 (1995).

27. Brown-Nagin, "The Constitution, the Law and Social Change."

28. Martin Luther King, Jr., "I Have a Dream," speech, August 28, 1963, Washington DC, transcript http://www.americanrhetoric.com/speeches/mlkihaveadream.htm (accessed July 18, 2018). For insightful analyses, see Eric J. Sundquist, King's Dream: The Legacy of Martin Luther King's "I Have a Dream" Speech (New Haven: Yale University Press, 2009); and Drew D. Hansen, The Dream: Martin Luther King, Jr., and the Speech that Inspired a Nation (New York: Ecco, 2003).

29. See Glenn T. Eskew, But for Birmingham: The Local and National Movements in the Civil Rights Struggle (Chapel Hill: University of North Carolina Press, 1997), 299-332.

30. See Gary May, Bending Toward Justice: The Voting Rights Act and the Transformation of American Democracy (New York: Basic Books, 2013), ix-x, 167-69. John Lewis called the passage of the Voting Rights Act the nation's "finest hour." See Clayborne Carson, "1965: A Decisive Turning Point in the Long Struggle for Voting Rights," The Crisis, July/August 2005, 16-20. 


\section{The Movement and Economic Inequality}

Nevertheless, the matter of economic inequality that A. Philip Randolph and others earlier had raised remained. ${ }^{31}$ Now, everyday people-mobilized by the movement but dissatisfied with the partial reforms embodied in antidiscrimination law-raised their voices: the radical labor activists in New York whom Martha Biondi describes, ${ }^{32}$ the proponents of black power in Philadelphia whom Matthew Countryman writes about in $U p$ South, ${ }^{33}$ organizers in Mississippi whose activities Charles Payne documented, ${ }^{34}$ and welfare rights protesters in Atlanta who are the third wave of dissenters in Courage to Dissent, ${ }^{35}$ all made economic opportunity central to their agendas.

Dr. King heard the call, Thomas Jackson explained in From Civil Rights to Human Rights. ${ }^{36}$ His commitment to a social contract that lifted the poor of all races found full expression during the mid-1960s. Dr. King visited slums in the urban North and South and argued that all Americans bore responsibility for conditions in the ghetto. ${ }^{37} \mathrm{He}$ turned to President Lyndon Johnson for solutions, demanding a "massive assault upon slums, inferior education, [and] inadequate medical care." 38 Dr. King sought job training and a guaranteed minimum income for all Americans. ${ }^{39}$ In 1965, Dr. King's analysis deepened. He spoke about the violence of poverty; he called imprisoned black men the "legion of the damned in our economic army." 40 In 1966, he observed that "depressed living standards" for the working poor were a "structural part of the economy," and that certain industries grossly profited from a steady supply of "unskilled" laborers ${ }^{41}$ — critiques that should sound familiar decades later.

31. Brown-Nagin, "The Civil Rights Canon," 2722-23.

32. Martha Biondi, To Stand and Fight: The Struggle for Civil Rights in Postwar New York City (Cambridge, MA: Harvard University Press, 2003).

33. Matthew J. Countryman, Up South: Civil Rights and Black Power in Philadelphia (Philadelphia: University of Pennsylvania Press, 2006).

34. Charles M. Payne, I've Got the Light: The Organizing Tradition and the Mississippi Freedom Struggle (Berkeley: University of California Press, 1995).

35. Brown-Nagin, Courage to Dissent, 4-5.

36. Thomas F. Jackson, From Civil Rights to Human Rights: Martin Luther King, Jr., and the Struggle for Economic Justice (Philadelphia: University of Pennsylvania Press, 2007), $160,171-72$.

37. Jackson, From Civil Rights to Human Rights, 2-3, 21, 33, 209, 350.

38. Ibid, 204.

39. Ibid, 192-94.

40. Michael E. Dyson, April 4, 1968: Martin Luther King, Jr.'s Death and How it Changed America (New York: Basic Civitas Books, 2008), 123.

41. Martin Luther King, Jr., Where Do We Go from Here: Chaos or Community? (New York: Harper \& Row, 1967), 163, 193. 


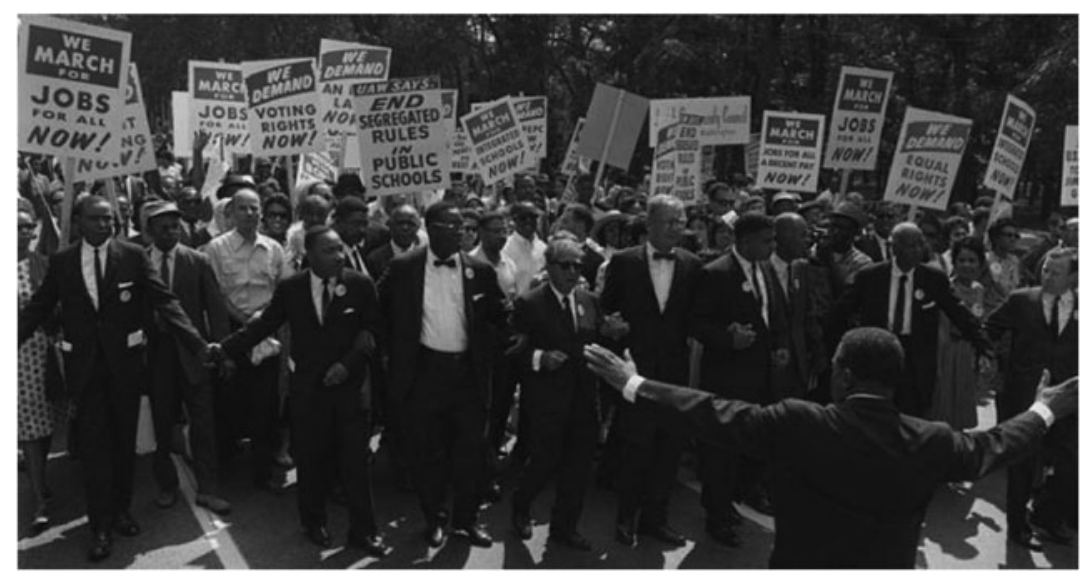

And in Memphis in 1968, Dr. King took up mantle of the labor movement. In "I've Been to the Mountaintop," his final public address, King defended the workers' agenda and their protest and urged America to "[b]e true to what you said on paper." "Somewhere I read of the freedom of assembly. Somewhere I read of the freedom of the press. Somewhere I read the greatness of America is the right to protest for right." 42 For the last time, Dr. King brilliantly deployed the Constitution to advance freedom for blacks, for whites, for workers: for downtrodden Americans everywhere.

Dr. King's foregrounding of economic justice engendered controversy. Some argued that Dr. King should, in essence, stay in his lane. ${ }^{43}$ Senator Daniel Patrick Moynihan claimed that "pathology" largely explained blacks' ills. ${ }^{44}$

But others, including Dr. King's lieutenant, Bayard Rustin, and student activists, endorsed the broader agenda. ${ }^{45}$ And now, let us consider that strand of the movement, a turn that will illustrate how activists deployed law as cultural and political resources.

42. Martin Luther King, Jr., "I've Been to the Mountaintop," speech, April 3, 1968, Memphis, transcript. http://kingencyclopedia.stanford.edu/encyclopedia/documentsentry/ive_been to the mountaintop/ (accessed July 18, 2018).

43. Jackson, From Civil Rights to Human Rights, 192.

44. Daniel P. Moynihan, The Negro Family: The Case for National Action, report (Office of Policy Planning and Research: United States Department of Labor, 1965).

45. See Brown-Nagin, "The Civil Rights Canon," 2722-26. 


\section{Law as Cultural and Political Resources}

First, I will consider SNCC, the student group nurtured by organizer Ella Baker, which consciously adopted an arsenal of tactics that varied from those favored by Dr. King and Thurgood Marshall. ${ }^{46}$ Like King and Marshall, SNCC deployed "rights talk." However, if Marshall made legal claims, and Dr. King evoked law for moral suasion, SNCC invoked the nation's founding documents and court cases to engage in cultural critique and to politicize and organize local people. ${ }^{47}$ If Marshall and the early Dr. King hoped to achieve reform by currying favor with the nation-state, SNCC hoped to be a countervailing force to elite domination and, if necessary, achieve freedom outside of the prevailing structures of society. ${ }^{48}$

SNCC alluded to what Edwin Corwin called the "cult of the Constitution" to expose American hypocrisy and to press an expansive agenda. ${ }^{49}$ In SNCC's telling, desegregation was a necessary, but insufficient, precondition to freedom. ${ }^{50}$ The students also demanded affordable housing, community schools, political power, and fair policing. ${ }^{51}$ Officers routinely brutalized blacks, particularly in impoverished communities; in fact, many officers, including Atlanta's chief of police from 1947 to 1972 , were members of the $\mathrm{Ku}$ Klux Klan. ${ }^{52}$ SNCC challenged American society, including liberal reformers in the NAACP, in the White House, and on the Supreme Court, to reject hypocrisy. ${ }^{53}$

Striking a contrast to Dr. King, who had praised Brown, SNCC argued that the Court's actions in Brown's aftermath illustrated that American institutions had failed African Americans. ${ }^{54}$ And the students cited disillusionment with courts and lawyers to justify more participatory tactics, a repertoire that included sit-ins, boycotts, picketing and community organizing, and a broader substantive agenda. The participatory forms of protest added something that court-based activism lacked: political struggle, unmediated by formalities, rules, lawyers,

46. See Clayborne Carson, In Struggle: SNCC and the Black Awakening of the 1960s (Cambridge, MA: Harvard University Press, 1981), 158-62, 207-11.

47. See Brown-Nagin, "The Constitution, the Law and Social Change."

48. Andrew S. McFarland, "Social Movements and Theories of American Politics," in Social Movements and American Political Institutions, eds. Anne N. Costain and Andrew S. McFarland (Oxford: Rowman \& Littlefield Publishers, 1998), 8, 11.

49. Edward S. Corwin, "The Constitution as an Instrument and Symbol," American Political Science Review 30 (1936): 1071-85, at 1078.

50. See Carson, In Struggle, 158-62, 207-11.

51. Ibid.

52. Brown-Nagin, Courage to Dissent, 35.

53. See Carson, In Struggle, 158-62, 207-11.

54. Ibid., 62-64; and Brown-Nagin, Courage to Dissent, 266. 


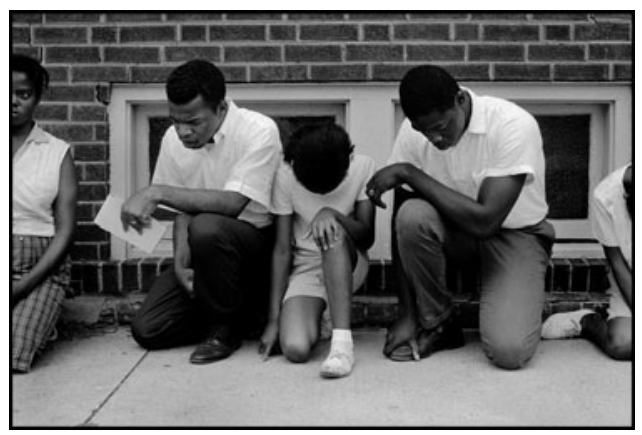

presidential politics, or judges in robes. ${ }^{55}$ John Lewis explained it best. "[W]e were all about" a "mass movement, an irresistible movement of the masses. Not a handful of lawyers in a closed courtroom, but hundreds, thousands of everyday people ... taking their cause and belief to the streets." 56

At the same time, SNCC continued to make claims on the law, only mostly outside of the courts, for their own purposes, and without a core belief in the efficacy of law. In protests in Atlanta, the students argued that foundational legal texts made promises that were not real, but fictive. ${ }^{57}$ One might say that these students, like A. Philip Randolph, were proponents of the idea that rights are "illusory." 58 All of these activists believed that the "myth of rights," to quote Stuart Scheingold, facilitated oppression. ${ }^{59}$

\section{Resistance Today}

As I think about today's Resistance and its rule of law goal, compared to the array of groups and legal tactics of yesterday, I am most struck by differences, rather than continuities. Although it is true that the Resistanceand the lawyers who, independently of it, have filed claims over emoluments and travel bans - charge this administration with violating constitutional norms, similarly to past movements that I have

55. Brown-Nagin, "The Constitution, the Law and Social Change."

56. Brown-Nagin, Courage to Dissent, 138.

57. Brown-Nagin, "The Constitution, the Law and Social Change."

58. See, generally, David Papke, Heretics in the Temple: Americans Who Reject the Nation's Legal Faith (New York: New York University Press, 1998).

59. Stuart A. Scheingold, The Politics of Rights: Lawyers, Public Policy, and Political Change (Ann Arbor: University of Michigan Press, 2004), 5. 


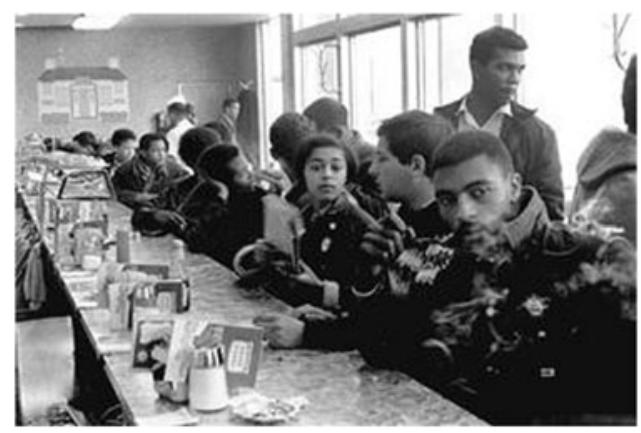

surveyed, ${ }^{60}$ more striking is the difference between the rhetorical strategies of the Resistance and those of these prior movements. Unlike these prior movements, ${ }^{61}$ the Resistance does not seek to build consensus between groups in conflict by emphasizing shared values, unifying themes, or a common purpose.

Much of the rhetoric employed by the Resistance is very specific, rather than abstract or inspirational. Marchers have held signs with allusions to "Resist," "Resist Bigly," and being "Woke,"62 as well as to Women's Anatomy Grabbing Back, ${ }^{63}$ Male Anatomy, ${ }^{64}$ Hitler, Facism, ${ }^{65}$ Not My

60. For the travel ban litigation, see, for example, Trump v. International Refugee Assistance Project, 137 S.Ct. 2080 (2017). For emoluments litigation, see Mark J. Stern, "Donald Trump is Now Facing Three Emoluments Lawsuits," Slate, June 14, 2017. http:// www.slate.com/articles/news_and_politics/jurisprudence/2017/06/trump_is_facing_three_emoluments_lawsuits_will_any_of_them_succeed.html (accessed July 18, 2018).

61. This article focuses on particular strands of particular social movements. For a movement with countercultural and more strident rhetorical strategies, consider, for example, the anti-war movement. See Theodore O. Windt, Jr., Presidents and Protestors: Political Rhetoric in the 1960s (Tuscaloosa: University of Alabama Press, 1991), 169-70.

62. For photographs of signs with these three allusions, see Ian Simpson and Joseph Ax, "Washington braces for anti-Trump protests, New Yorkers march," Reuters, January 19, 2017. https://www.reuters.com/article/us-usa-trump-protests/washington-braces-for-antitrump-protests-new-yorkers-march-idUSKBN1531GH (accessed July 18, 2018).

63. See Jon Sharman, "The Best Women's March signs from around the world as feminists protest Donald Trump," The Independent, January 22, 2017. http://www.independent. co.uk/news/world/americas/womens-march-best-signs-pictures-around-the-world-donaldtrump-protest-feminism-a7539871.html (accessed July 18, 2018).

64. See Daniel Albanese, "LGBT Rally," Dusty Rebel (blog), February 5, 2017. http:/ www.thedustyrebel.com/post/156847308822/i-like-dick-i-like-taters-not-dictators-lgbt-rally (accessed July 18, 2018).

65. Keri Phillips, "Is it Fair to Call Donald Trump a fascist?," ABC News, March 6, 2017. http://www.abc.net.au/news/2017-03-07/is-it-fair-to-call-trump-a-fascist/8328888 (accessed July 18, 2018). 

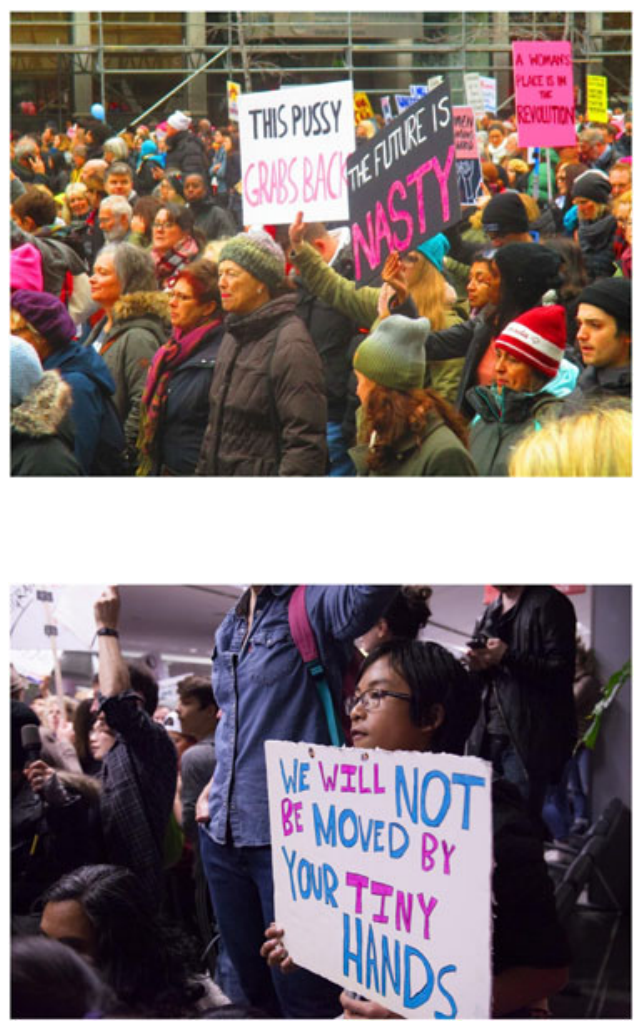

President, ${ }^{66}$ and Not My Cheeto. ${ }^{67}$ And my favorite sign of them all said: "It's so bad, even introverts are here!"68 This is scathing and incredibly amusing rhetoric - the kind that goes viral and is tweeted and retweeted.

The Resistance has made us laugh, but has it persuaded those not already inclined to support its point of view (and its sense of humor)? Such efforts to persuade might be premised on the kinds of eloquent critiques observed in the strands of the civil rights, women's rights, abolition,

66. Alan Taylor, “'Not My President': Thousands March in Protest," Atlantic, November 10, 2016. https://www.theatlantic.com/photo/2016/11/not-my-president-thousands-march-inprotest $/ 507248 /$ (accessed July 18, 2018).

67. Brian Josephs, "These are the Best Protest Signs We Saw at the Women's March on Washington and New York," Spin, January 22, 2017. https://www.spin.com/2017/01/protest-signs-womens-march/ (accessed July 18, 2018).

68. Sophia Dembling, "Even Introverts Are Here,” Psychology Today, January 24, 2017. https://www.psychologytoday.com/blog/the-introverts-corner/201701/even-introverts-are-here (accessed July 18, 2018). 
and suffrage movements discussed here. To my knowledge, the Resistance has not embraced rhetorical strategies premised on unifying legal precepts and national ideals: speech designed to rally friends and persuade enemies. And, I wonder if the frenzied pace of our time, facilitated by digital platforms, has undercut the sustained, intellectual, cultural, and political work in the public square necessary to persuade the public of the rightness of a protest movement's claims. Such narrative strategies are, it seems to me, a necessary precondition to political and legal change, which is based, after all, on the persuasive arts.

\section{The Long Resistance: Abolitionism}

I mentioned abolitionism, and I want to return to it to drive home the temporal point that I hope to make. Dr. King once observed that the "arc of the moral universe is long, but it bends toward justice." 69 The concept of the "long resistance" embeds in scholarship the expansive temporal element that Dr. King referenced. Scholars such as Jacqueline Dowd Hall have argued for a "long" conception of the civil rights movement, one that locates its roots in the labor conflicts of the $1930 \mathrm{~s}^{70}$ Other scholars advocate an even longer temporal arc, one that stretches the movement's heritage back to the nineteenth-century fight against slavery: the defining struggle over labor in the United States. ${ }^{71}$ It is especially important now to reckon with slavery and abolitionism, it seems to me-in an age when scholars such as Sven Beckert ${ }^{72}$ and Edward Baptist ${ }^{73}$ have explained how global slavery laid the groundwork for both modern prosperity and modern inequality - and when communities contend, sometimes violently, with monuments to slave holders and Confederates.

If Plessy v. Ferguson (1896) framed twentieth-century disputes over racial inequality, ${ }^{74}$ Dred Scott v. Sandford (1857) stirred nineteenth-

69. This quote is actually credited by some to Rev. Theodore Parker, an abolitionist. Dr. King later adapted to the twentieth-century context. See Jamie Stiehm, "Oval Office rug gets history wrong," Washington Post, September 4, 2010.

70. Jacqueline Dowd Hall, "The Long Civil Rights Movement and the Political Uses of the Past," Journal of American History 91 (2005): 1233-63.

71. See generally Zoe Frances Trodd, The Reusable Past: Abolitionist Aesthetics in the Protest Literature of the Long Civil Rights Movement (Cambridge, MA: Harvard University, 2009).

72. See, generally, Sven Beckert and Seth Rockman, eds., Slavery's Capitalism: A New History of American Economic Development (Philadelphia: University of Pennsylvania Press, 2016).

73. See, generally, Edward E. Baptist, The Half Has Never Been Told: Slavery and the Making of American Capitalism (Philadelphia: Basic Books, 2014).

74. Plessy v. Ferguson, 163 U.S. 537 (1896). 


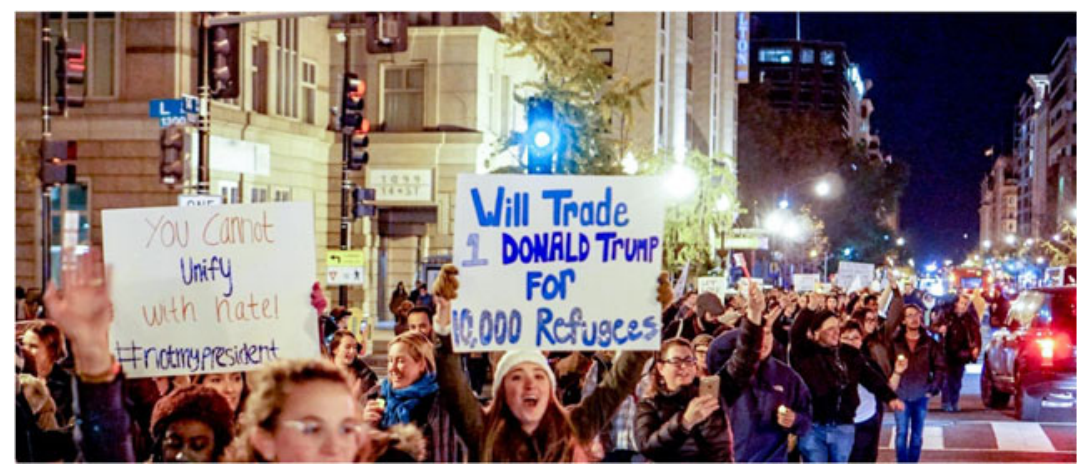

century activism. ${ }^{75}$ The case denying citizenship to persons of African descent inspired fervent abolitionist resistance. ${ }^{76}$ Activists critiqued the case and the Fugitive Slave Law, and they deployed rights talk for moral suasion, for political and cultural mobilization, and to make legal claims. ${ }^{77}$

Consider Frederick Douglass's 1860 speech arguing that the original Constitution did not, in fact, support slavery. Douglass reached this conclusion through an ingenious textual interpretation, one that rested in part on his reading of the preamble to the Constitution to achieve his moral and political purposes. "The Constitution['s] ... language is "we the people," he noted, "not we the white people." Therefore, he "denied that the Constitution guarantees the right to hold property in man."78

William Lloyd Garrison, publisher of the Liberator and leader of the Massachusetts Anti-Slavery Society, shared Douglass' anti-slavery purpose, but not his constitutional interpretation. ${ }^{79}$ Douglass was to Garrison as Dr. King was to SNCC.

Garrison called the Constitution a "bloody" and "wicked" compact. ${ }^{80}$ And in an 1854 Fourth of July rally—where he stood on a stage decorated

75. Dred Scott v. Sandford, 60 U.S. 393 (1857).

76. See Don E. Fehrenbacher, The Dred Scott Case: Its Significance in American Law and Politics (New York: Oxford University Press, 1978), 160-62, 278-79, 287, 341-342.

77. Brown-Nagin, "The Constitution, the Law and Social Change."

78. Frederick Douglass, "The Constitution of the United States," speech, March 26, 1860, Glasgow, Scotland, transcript. http://teachingamericanhistory.org/library/document/the-constitution-of-the-united-states-is-it-pro-slavery-or-anti-slavery/ (accessed July 18, 2018).

79. William Lloyd Garrison, "On the Constitution and the Union," Liberator, December 29, 1832. http://fair-use.org/the-liberator/1832/12/29/on-the-constitution-and-the-union (accessed July 18, 2018).

80. Ibid. 


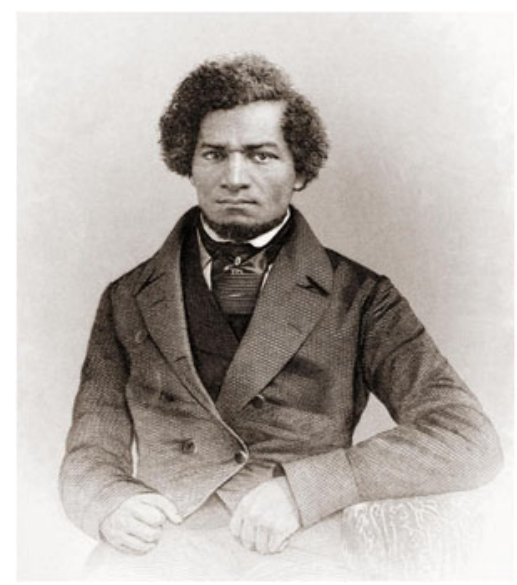

with an inverted United States flag-Garrison lit a match to the Constitution (and the Fugitive Slave Law). ${ }^{81}$

His dramatic display of contempt for the Constitution reflected the times, and presaged the Civil War to come.

\section{Suffrage}

Illustrating how protest movements beget movements, leaders of the National Woman Suffrage Association, Susan B. Anthony and Elizabeth Cady Stanton, organized a multifaceted suffrage strategy that borrowed some tactics from abolitionism. ${ }^{82}$ The tactics included litigation, lobbying, and civil disobedience. ${ }^{83}$ Perhaps most famously, Anthony voted illegally in the presidential election of 1872, and then gave an address during which she, echoing Frederick Douglass, cited the preamble to the Constitution to justify her action. ${ }^{84}$

81. See Paul Finkelman, "Garrison's Constitution: The Covenant with Death and How it was Made," Prologue: Quarterly of the National Archives 32 (2000): 231-45 and Henry Mayer, All on Fire: William Lloyd Garrison and the Abolition of Slavery (New York: W. W. Norton \& Co, 1998).

82. See Aileen S. Kraditor, The Ideas of the Woman Suffrage Movement, 1890-1920 (New York: W.W. Norton, 1981), 43-74.

83. Ibid. at $219-48$.

84. Susan B. Anthony, "On Women's Right to Vote," speech, 1873, New York, transcript. http://www.historyplace.com/speeches/anthony.htm (accessed July 18, 2018); also see Reva B. Siegel, "She the People: The Nineteenth Amendment, Sex Equality, Federalism and the Family," Harvard Law Review 115 (2002): 948-1046. 


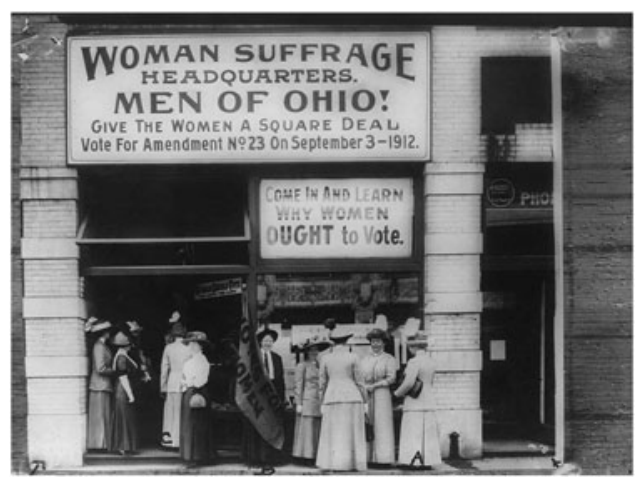

The preamble to the Constitution says: "[W]e, the people; not we, the white male citizens; nor yet we, the male citizens; but we, the whole people, who formed the Union." 85 Therefore, she argued, citizenship did not exclude women.

Despite the elegance of Anthony's speech, women only gained suffrage after the face of the Constitution itself changed in 1920, when states ratified the Nineteenth Amendment to the Constitution. ${ }^{86}$

\section{Women's Liberation}

Then, in the twentieth century, proponents of "women's liberation" attacked sex discrimination that persisted in social life, politics, and the workplace despite the Nineteenth Amendment. In court, lawyers drew analogies to race discrimination - now constitutionally and statutorily proscribed. In the words of Serena Mayeri, women "reasoned from race," and with considerable success. ${ }^{87}$

And, in a replay of some of the dynamics in the civil rights movement, some women's liberation activists criticized the reliance on courts to do the cultural work of ending male domination. The Fourteenth Amendment demanded that women conform to the male norm, a version of equality that fell far short of liberation. 88 That type of argument would never destroy male supremacy — no more than a constitutional suit could destroy white supremacy.

85. Anthony, "On Women's Right to Vote."

86. Serena Mayeri, Reasoning from Race: Feminism, Law and the Civil Rights Revolution (Cambridge, MA: Harvard University Press, 2011), 14.

87. Ibid., 5.

88. See Zillah R. Eisenstein, The Radical Future of Liberal Feminism (Boston: Northeastern University Press, 1993), 177-79. 
Sounding like SNCC, feminist critics argued that true liberation demanded critiques not only of cultural norms, but also of economic structures. Conflict occurred as economically secure, middle-class reformers in the National Organization of Women (NOW) sought inclusion in the workplace, while working-class and poor women, many of them black and Hispanic, urged a focus on issues economic at their core. ${ }^{89}$

Women's different priorities can be seen in the varieties of feminism that flowered: socialist feminists; ${ }^{90}$ welfare rights activists led by Johnnie Tillman, a sharecropper's daughter, who hoped for a living wage that would enable women to avoid welfare; ${ }^{91}$ black and Chicana feminists, who foregrounded intersectional oppression (based on race, ethnicity and class, sex, and sexuality); $; 2$ feminists focused on reproductive rights and women's health; ${ }^{93}$ women seeking to end male cultural dominance; ${ }^{94}$ and always, women demanding greater employment opportunity, equal pay, and the Equal Rights Amendment (ERA). ${ }^{95}$

Amid the ascent of the feminisms, the political opportunity structure changed. Richard Nixon - the voice of a silent majority premised on white identity and backlash to anti-war and civil rights activism-took office. Although Nixon did sign Title IX of the 1972 Education Amendments and endorsed the ERA, ${ }^{96}$ he vetoed the first federal legislation providing comprehensive childcare assistance, denouncing it as "radical," which I think was the point. ${ }^{97}$ And then there was Watergate, Nixon's resignation, and the loss of faith in American institutions. ${ }^{98}$

89. Ibid., 176-78.

90. Ibid., 180.

91. Canela A. Jaramillo, "Feature: A Tribute to Johnnie Tillmon," Standard, Spring/ Summer, 2001. https://www.colorado.edu/journals/standards/V7N2/feature.html (accessed July 18, 2018).

92. See Benita Roth, Separate Roads to Feminism: Black, Chicana and White Feminist Movements in America's Second Wave (New York: Cambridge University Press, 2003).

93. See Mary Ziegler, "The Price of Privacy: 1973 to the Present," Harvard Journal of Law and Gender 37 (2014): 285-329.

94. See, generally, Eisenstein, The Radical Future of Liberal Feminism.

95. See Janet K. Boles, The Politics of the Equal Rights Amendment: Conflict and the Decision Process (New York: Addison-Wesley Longman, 1979).

96. See Boles, The Politics of the Equal Rights Amendment, 128.

97. See Lynn Olson, "Nixon Leaves Mixed Legacy on Education, Family Issues," Education Week, May 4, 1994. https://www-edweek-org.ezp-prod1.hul.harvard.edu/ew/articles/1994/05/04/32nixon.h13.html?qs=nixon+childcare (accessed July 18, 2018).

98. See Nancy Balfour, "The US Presidency in Danger," Royal Institute of International Affairs 29 (1973): 505-13. 


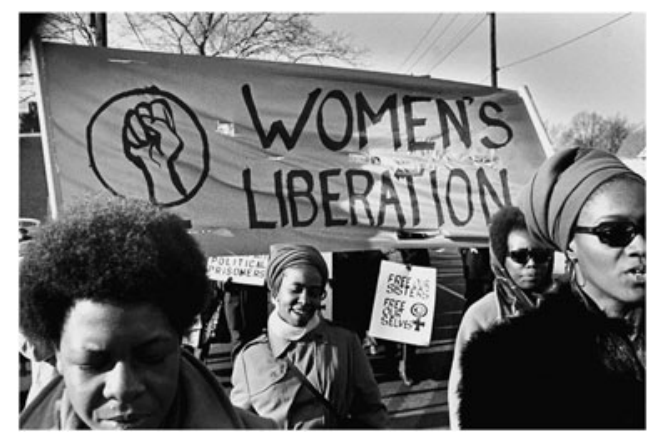

\section{The Relationship Between Movements and Electoral Politics}

The allusion to Nixon brings me to the relationship between protest movements and electoral politics. One of the most striking features of today's Resistance is its characterization as a millions-strong group laser-focused on defeating Trump. This is definitely a moment that the Democrats should be able to capitalize upon.

As a student of long resistance, I find myself given pause by the singular focus on electoral politics, much of which is media analysis but some of which reflects efforts by donors to funnel the energies of the Resistance into electoral politics ${ }^{99}$ to tame and constrain popular discontent. I suggest that the zero-sum dynamics of partisan politics is a strikingly narrow framework for analyzing both what is at stake and the value added by grassroots, popular movements.

Historically, many of these movements organized for change-in society and culture, as well as in law and public policy — while deliberately avoiding domination by the two parties. ${ }^{100}$

The civil rights movement did collaborate with particular political figuresthink Dr. King and President Lyndon Johnson-but only when doing so suited the movement. ${ }^{101}$ Through discussions with President Johnson over the need for economic redress for blacks and for all Americans suffering economic hardship, Dr. King helped secure the Economic Opportunity Act (EOA) of 1964, the legislative centerpiece of the War

99. See, for example, Kenneth P. Vogel, “The 'Resistance,' Raising Big Money, Upends Liberal Politics," New York Post, October 7, 2017. https:/www.nytimes.com/2017/10/07/us/ politics/democrats-resistance-fundraising.html (accessed July 18, 2018).

100. See Brown-Nagin, "The Civil Rights Canon,” 2711.

101. Ibid. 
on Poverty. ${ }^{102}$ Some of the War on Poverty programs did, in fact, help to disestablish the racial state that New Deal social programs had kept firmly intact. ${ }^{103}$ In the Deep South, movement allies leveraged the concept of community action embedded in the EOA to benefit tenant farmers, manual laborers, and other hardworking people, attaining grants for housing and education. ${ }^{104}$ As Gavin Wright, the professor of economic history showed in his book, Sharing the Prize, these grants made a difference. Between 1959 and 1978, the Southern black rural poverty rate declined from $77.7 \%$ to $37.2 \% .{ }^{105}$

Nevertheless, conceptually, President Johnson-who championed a hand-up rather than a handout - eschewed Dr. King's idea of a minimum income. Hence, the poverty programs did not go nearly as far as Dr. King and others had wanted. ${ }^{106}$

For this reason, SNCC and Ella Baker-grassroots proponents of an antipoverty vision of human rights - thought of Dr. King's alliance with President Johnson as a "malignant kinship."107 The students disdained the strategic political alliances that yielded compromise legislation. People in local communities - who were bereft of basic daily needscould not afford compromise, the group argued. Harshly criticizing the Democratic Party, SNCC pushed for a more progressive sociolegal agenda, one that empowered local people. ${ }^{108}$

SNCC - which had witnessed squalor and hunger, dilapidated houses, and crumbling schools in the North and South-kept pushing for more. Some in SNCC, like Julian Bond and John Lewis, transitioned from "protest to politics," as Bayard Rustin suggested. ${ }^{109}$ They sought to become the elected officials and party leaders they had hoped for. Civil rights lawyers filed suits attacking exclusion from the state and local political apparatus. ${ }^{110}$ In short, activists took democracy into their own hands.

102. Brown-Nagin, "The Civil Rights Canon," 2730.

103. See Karen Ferguson, Black Politics in New Deal Atlanta (Chapel Hill: University of North Carolina, 2002), 22-23; and Ira Katznelson, Fear Itself: The New Deal and the Origins of Our Time (New York: Liveright Publishing, 2013), 159-63.

104. Payne, I've Got the Light, 338-39; and Carson, In Struggle, 258-59.

105. Gavin Wright, Sharing the Prize: The Economics of the Civil Rights Revolution in the American South (Cambridge, MA: Harvard University Press, 2013).

106. Jackson, From Civil Rights to Human Rights, 8.

107. Brown-Nagin, "The Civil Rights Canon," 2715.

108. Ibid.

109. See Bayard Rustin (ed. Michael Long), I Must Resist: Bayard Rustin's Life in Letters, (San Francisco: City Lights, 2012).

110. Susan Youngblood Ashmore, Carry It On: The War on Poverty and the Civil Rights Movement in Alabama, 1964-72 (Athens: University of Georgia Press, 2008), 158, 247-49. 


\section{The Long Political Resistance}

SNCC was hardly alone. The women's liberation movement included a variety of organizations focused on different objectives - none defined by a political party. The tradition of political independence even occurred when women attained political office and nominally represented the system.

Shirley Chisholm won a seat in Congress as a Democrat, but famously proclaimed herself Unbought and Unbossed.11 The Brooklyn Congresswoman refused Democrats' plea to be a "good soldier" and accept an assignment to the House Agricultural Committee and subcommittees focused on "rural development and forestry." 12 It was "hard to imagine," she protested, "an assignment less relevant to her background or to her predominantly black and Puerto Rican district in Brooklyn, where many residents were unemployed, hungry, and badly housed." 113 Chisholm won that battle, and later she critiqued the entire political system in still relevant terms: "“'It is incomprehensible to me, the fear that can affect men in political offices. It is shocking the way they submit to forces they know are wrong and fail to stand up for what they believe. Can their jobs be so important to them, their prestige, their power, their privileges. . .that they will cooperate in the degradation of society just to hang onto those jobs?... Our representative democracy is not working." 114

Also think of Bella Abzug, another New York Congresswoman, known for denouncing her colleagues as a privileged elite out of touch with America. She, too, refused to go along with political compromises just to get along. ${ }^{115}$ In 1978, President Jimmy Carter fired Abzug from her position as co-chairwoman of the National Advisory Committee for Women; the firing stemmed from Carter and Abzug's "stormy relationship," illustrated by incidents such as Abzug's giving a "lecture" to the president on the committee's proper role, and her cancellation of a meeting with the White House because it was limited to 15 minutes. ${ }^{116}$

111. Shirley Chisholm (ed. Scott Simpson), Unbought and Unbossed: Expanded 40th Anniversary Version (Boston: Take Root Media, 2010).

112. Ibid., 99-100.

113. Ibid., 101.

114. Ibid., 102.

115. Alan H. Levy, The Political Life of Bella Abzug, 1920-1976: Political Passions, Women's Rights, and Congressional Battles (Plymouth: Lexington Books, 2013), 86.

116. See Edward Walsh, "Abzug Praises President - And Then He Fires Her," Washington Post, January 13, 1979. https://www.washingtonpost.com/archive/politics/ 1979/01/13/abzug-praises-president-and-then-he-fires-her/e17b21d7-85cf-4a48-9a2a-361e097 97603/?utm_term=.ac4e6ebe6ef5 (accessed July 18, 2018). 


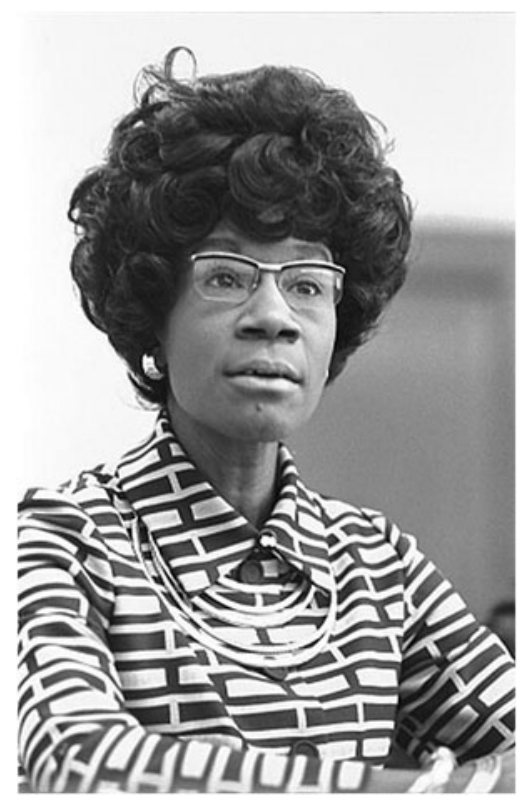

And so we see that the tradition of political independence-like the resistance itself-is long. Whether abolitionists, woman suffrage advocates, or welfare rights activists, those in progressive change movements have gained influence by disrupting politics as usual — not by aligning lockstep with electoral parties. Activists accepted the support of parties, but demanded the autonomy necessary to define and control their missions, create their own narratives, and maintain enough distance to critique the overarching structure of the system - which long ago they called rigged. That is how grassroots social movements-as opposed to interest or lobbying groups - typically function, in full recognition that the arena of national electoral politics is not the place to expect the full realization of a movement's agenda. The emphasis here is on full.

Years after the election of a critical mass of women and minorities, political scientists confirmed how difficult it is for them to translate descriptive into substantive representation, truly representing the interests of constituents. ${ }^{117}$ Moreover, the decades-long contest over gerrymandering has

117. See Brown-Nagin, Courage to Dissent, 58; and Kristin Kanthak and George Krause, The Diversity Paradox: Parties, Legislatures, and the Organizational Foundations of Representation in America (New York: Oxford University Press, 2012). 


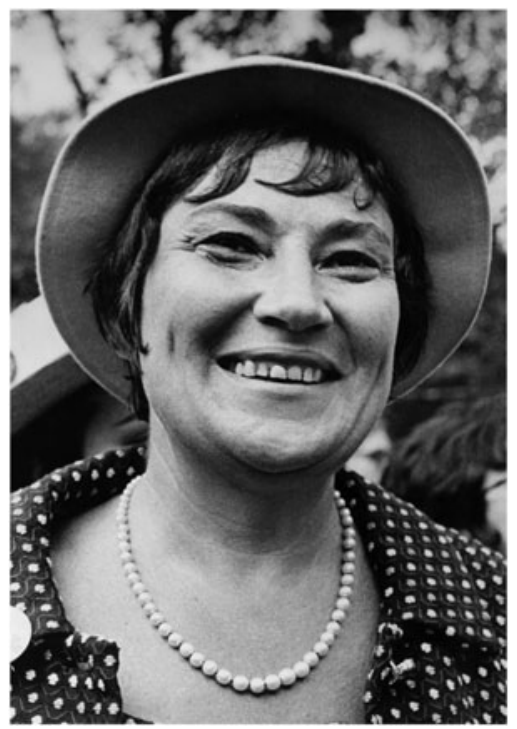

seriously fettered their power, and some scholars fear, representative democracy itself. ${ }^{118}$

\section{Resistance Today: The Tea Party Analogy}

My analysis of the relationship between protest movements and formal politics calls into question much of recent commentary drawing connections between the present Resistance and the Tea Party.

The Tea Party is a model for the current Resistance, it is said, because it translated popular dissatisfaction with Washington into policy priorities. ${ }^{119}$ The Tea Party was definitely effective in many ways. One can see echoes in the Tea Party of some of the tactics and narrative strategies that I associated with the civil rights movement. ${ }^{120}$ The Tea Partiers wrapped

118. See Margaret Levi, James Johnson, Jack Knight, Susan Stokes, eds., Designing Democratic Government: Making Institutions Work (New York: Russell Sage Foundation, 2008), 189-224.

119. See Vanessa Williamson and Theda Skocpol, "What can (and should) activists learn from the Tea Party?" Washington Post, May 11, 2017. https://www.washingtonpost.com/ news/monkey-cage/wp/2017/05/11/what-can-or-should-activists-learn-from-the-tea-party/? utm_term=.a7e072af6654 (accessed July 18, 2018).

120. Tomiko Brown-Nagin, "To better understand the future of protest, we need to look at its past," Pacific Standard, March 9, 2017. https://psmag.com/news/to-better-understand-thefuture-of-protest-we-need-to-look-at-its-past (accessed July 18, 2018). 


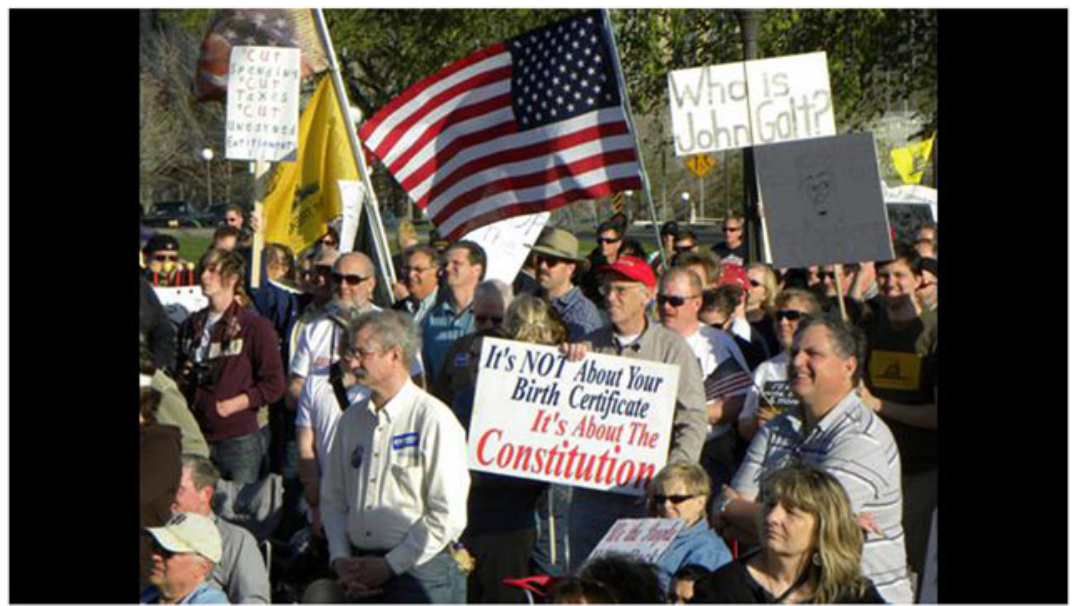

themselves in the flag and repeatedly invoked legalistic concepts, including the aspirational language of We the People, liberty, and equality. ${ }^{121}$ And the name - Tea Party - is evocative. Yet, even setting aside the white racial identity politics embedded in many Tea Party critiques of the ACA, the analogy strikes me as problematic. ${ }^{122}$

The political scientist Theda Skocpol has shown that, contrary to media mischaracterizations, the Tea Party was not merely a popular insurgency. ${ }^{123}$ In the wake of electoral defeat in 2008, Republican political operatives, wealthy businessmen and foundations, and media elites such as Glenn Beck manufactured a backlash against Obama, the ACA, and new social programs. ${ }^{124}$ The concerted effort exploited racial resentment and anxiety about handouts to the "undeserving poor," to use Martin Gilens' term, ${ }^{125}$ among a minority of voters, disproportionately male, older, and white.

121. See "Our Republic at 230," Documents, Georgia Tea Party, 2018. http://georgiateaparty.org/documents/ (accessed July 18, 2018).

122. See, for example, Jesse Ferguson, "The Resistance is the majority of Americansnot a new Tea Party," Time, February 21, 2017. http://time.com/4676825/democratic-resistance-tea-party/ (accessed July 18, 2018).

123. See, for example, Skocpol and Williamson, The Tea Party, 1-11.

124. Ibid, 130.

125. Martin Gilens, Why Americans Hate Welfare: Race, Media and the Politics of Antipoverty Policy (Chicago: University of Chicago Press, 1999), 61. 
Thus, the Tea Party is best understood as an anti-tax, anti-regulation mobilization by corporations and foundations - complete with paid operatives, staged demonstrations and a disinformation campaign. ${ }^{126}$ It was not really a grassroots revolt, although the grassroots were mobilized in support of backers' policy priorities. ${ }^{127}$ The Tea Party mostly represents the manipulation of democracy, not its manifestation.

What, then, is there in the Tea Party for the anti-Trump Resistance to replicate? The suggestion would make sense if the interests of the Resistance and some political party aligned - which is not a judgment for me to make. Nevertheless, given the deep policy divisions on the Left seen in the run-up to the last election, interest convergence seems doubtful. ${ }^{128}$ Perhaps the analogy does make sense to the extent that it suggests the need for grassroots state and local organizing. A better analogy for the Resistance are the kinds of protest movements I have described here - ones that pushed and pulled the Democratic Party closer to its agenda.

\section{Historical Memory}

I will conclude with some thoughts about historical memory-views generated, in part, by the wide dissemination of the idea that contemporary protest groups and normal political institutions are of a piece. That very idea suggests selective memory: one cannot seriously entertain that thought and be aware of the points that I just made about progressive social movements' historic political independence.

I also have made the point that, although we remember movements in ways that emphasize distinctiveness, it is vitally important to appreciate the connections among them-particularly the economic thread. One cannot really understand the civil rights struggles without a deep appreciation of the labor movements and women's liberation. The shared agenda of the great twentieth-century social movements to remake the social contractthe push for greater fairness - is an overarching theme of these movements, and that aspiration still resonates in our time.

As we, as scholars and citizens, seek a more synthetic and holistic understanding of history, we must make the cultural backlash to progressive

126. Skocpol and Williamson, The Tea Party, 9-13.

127. Ibid, 11-13.

128. Gabriel Debenedetti, "Democrats sweat Clinton v Sanders rift," Politico, January 16, 2017. https://www.politico.com/story/2017/01/democrats-clinton-sanders-dnc-233648. 
social movements a more prominent part of our discussion and analysis. We have not sufficiently documented or analyzed right-wing protest movements. Our scholarship and our collective memory do encompass symbols of hate and white resistance such as Bull Connor, ${ }^{129}$ George Wallace, ${ }^{130}$ and Orval Faubus, ${ }^{131}$ and these men are easy to caricature, compartmentalize, or dismiss into the dustbins of history.

I refer, instead, to studies of everyday people and institutions, the places where cultures of white resistance persisted and proliferated despite the civil rights movement and against the backdrop of a global war on terror - the coming of age period for the young white supremacists on the streets of Charlottesville. ${ }^{132}$ We have not imagined an effective language for describing and explaining these phenomena.

The effects of this selective memory left journalists and some scholars surprised by the open white supremacy we have witnessed in this country in recent months. ${ }^{133}$ It leads students supposedly protesting fascism to shout down the supposed fascists, totally unaware of the irony. ${ }^{134}$

We would be less surprised by these currents if we paid sufficient attention to the scholarship that does exist on right-wing social movements. Consider Jason Sokol's exploration of the loss of racial status

129. Bull Connor was the commissioner of public safety in Birmingham, Alabama. During 1963, he directed the use of attack dogs against civil rights activists. BrownNagin, Courage to Dissent, 218.

130. George Wallace was a long-serving governor of Alabama, who in his inaugural speech stated "segregation now, segregation tomorrow, segregation forever." He did later, however, repent his views on segregation. See Carl T. Rowan, "The Rehabilitation of George Wallace," Washington Post, September 5, 1991. http://www.washingtonpost.com/ wp-srv/politics/daily/sept98/wallace090591.htm (accessed July 18, 2018).

131. Orval Faubus was the governor of Arkansas who opposed the desegregation of the Little Rock School District. See Elizabeth Jacoway, Turn Away the Son: Little Rock, the Crisis that Shocked the Nation (New York: Free Press, 2007).

132. Charlottesville was the site of white nationalist protests in 2017, where woman was killed after one of these protesters ran his car into a crowd of counterprotestors. See Ellie Silverman and Michael Laris, "Charlottesville victim: "She was there standing up for what was right'," Washington Post, August 13, 2017. https://www.washingtonpost.com/ local/public-safety/charlottesville-victim-she-was-there-standing-up-for-what-was-right/2017/08/ 13/00d6b034-8035-11e7-b359-15a3617c767b_story.html?utm_term=.bb778eb93f11 (accessed July 18, 2018).

133. See, for example, Matthew Delmont, "African Americans fighting fascism and racism, from WWII to Charlottesville," The Conversation, August 21, 2017, https://theconversation.com/african-americans-fighting-fascism-and-racism-from-wwii-to-charlottesville-82551 (accessed July 18, 2018).

134. See Michael H. Schill, "The misguided student crusade against 'Fascism'," New York Times, October 23, 2017. https://www.nytimes.com/2017/10/23/opinion/fascism-protest-university-oregon.html?mtrref-www.google.com\&assetType=opinion (accessed July 18, 2018). 


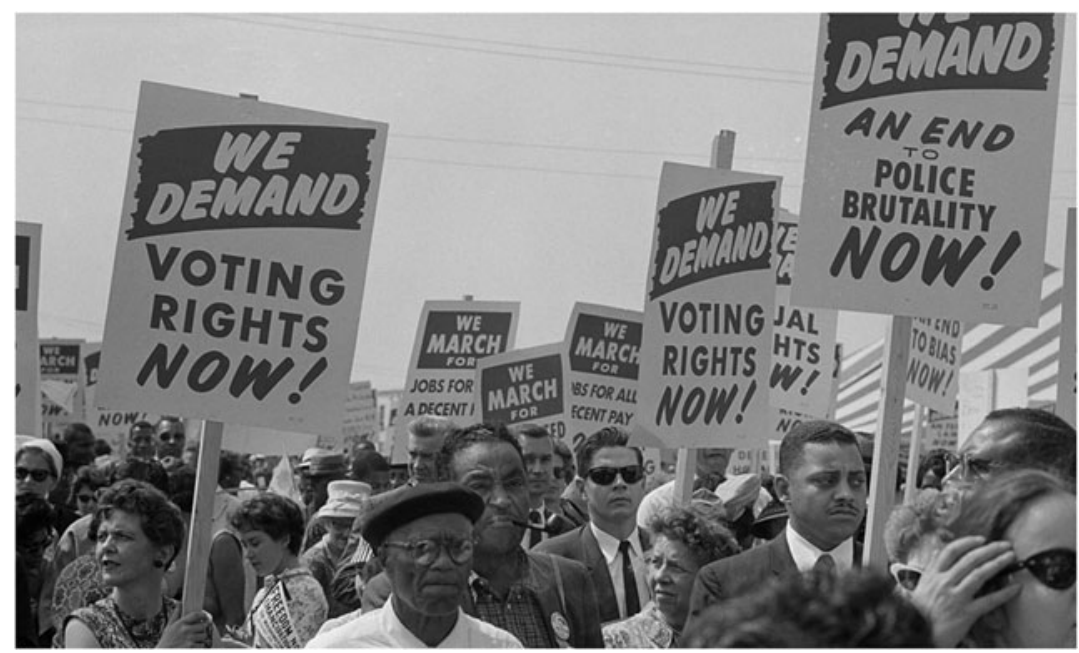

and its cultural meaning for white Southerners during the age of civil rights, aptly named: There Goes My Everything, a book filled with stories about change, as well as continuity, in social relations after the civil rights resolution. ${ }^{135}$

Nancy MacLean's Democracy in Chains also offers vital insights. MacLean locates the roots of certain strands of libertarian policies touted by elites in massive resistance to Brown v. Board of Education; these same libertarians, led by the Koch brothers, have captured much of our government, she argues. ${ }^{136}$

Finally, we, whether in memory or in scholarship, have not fully come to terms with forms of the protest against the wretched life conditions experienced by poor men, women, and children, particularly people of color, whether as seen in the Black Power movement or in the Movement for Black Lives. This is true, even though, for years now, scholars such as Peniel Joseph, 137

135. Jason Sokol, There Goes My Everything: White Southerners in the Age of Civil Rights, 1945-1975 (New York: Alfred A. Knopf, 2006).

136. Nancy MacLean, Democracy in Chains: The Deep History of the Radical Right's Stealth Plan for America (New York: Viking, 2017).

137. See Peniel Joseph, ed., The Black Power Movement: Rethinking the Civil RightsBlack Power Era (New York: Routledge, 2006); and Peniel Joseph, Waiting 'til the Midnight Hour: A Narrative History of Black Power in America (New York: Henry Holt, 2006). 


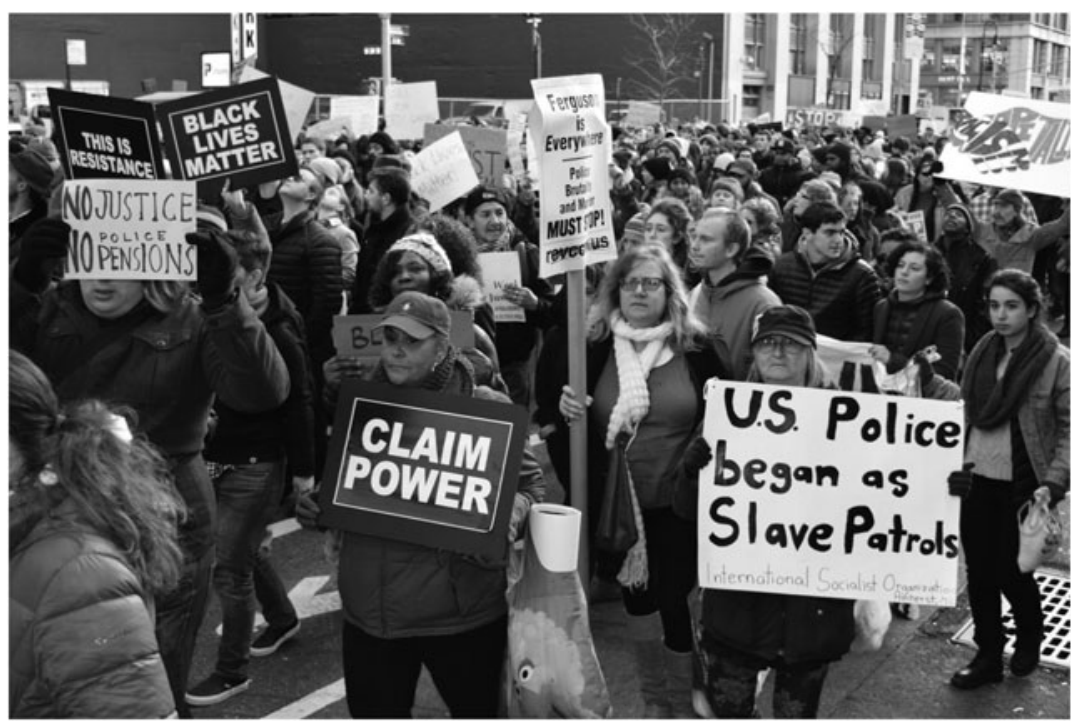

Matthew Countryman, ${ }^{138}$ Robert Self, ${ }^{139}$ and others ${ }^{140}$ have explained that Black Power, despite the narrowness evoked by the name, related to subjects relevant to any other history of the post-industrial state: to questions about jobs, taxes, schools, and policing.

A similar claim can be made about the Movement for Black Lives, which is not covered with the same interest, depth, or empathy as the part of the Resistance focused on electoral politics, or mentioned in the same voice as the historic struggles for equality that we now concede rooted out long-standing oppression in our society. Nevertheless, the connections to the long struggle for black freedom are clear. Consider this passage from Courage to Dissent.

Despite persistent complaints by black citizens from all walks of life about unlawful arrest and police brutality, local judges invariably sided with white officers. A judge dismissed charges against one officer accused of

138. See Countryman, Up South.

139. See Robert O. Self, American Babylon: Race and the Struggle for Postwar Oakland (Princeton: Princeton University Press, 2003).

140. See, for example, Fabio Rojas, From Black Power to Black Studies: How a Radical Social Movement Became an Academic Discipline (Baltimore: John Hopkins University Press, 2007). 
beating a 21-year old black man, Earl Sands, with a black jack and an iron link chain. The officer, who was cruising in his police car, claimed that Mr. Sands had disturbed the peace on Sands' walk from one house to another-two doors down - at 2 am on August 7, 1940. The officer alleged that Sands had resisted arrest; the young man proclaimed his innocence and begged to go home to his wife and child. In dismissing the complaint against the white officer, Judge Robert Carpenter commended him, saying, 'being a police officer is no easy job.' ${ }^{141}$

That passage, in broad outlines, could have been written about events in 1950, 1960, 1970, 1980, 1990, 2000, last year, or last month.

In continuing a long struggle against excessive use of force, the Movement for Black Lives makes a demand for the most basic human right of all, bodily integrity - along with a plea for a fair share of resources and investment in predominantly poor, minority communities.

Some of the movement's rhetoric sounds remarkably like the moral claims-making and cultural critique that we associate with Dr. King and SNCC. One wonders why, in a nation that now valorizes Dr. King, so many still cannot hear the claims of Black Lives Matter.

\section{Conclusion}

Thus, I conclude that what looks new must be seen in light of old and enduring dilemmas deeply rooted in social, political, and economic conflict. The interrelated conflicts bring to mind Dr. King's indictment, so many years ago, of the triple evils of "poverty, racism and militarism."142 The present conflicts hearken to foundational struggles over how to reconcile liberty, equality, and property rights.

Only now we debate the nature of a social contract in the wake of deindustrialization, deregulation, financial crisis, perpetual war, Google and Amazon, Twitter and Facebook, and yes, reality television, the cult of celebrity, and what it has wrought.

141. Brown-Nagin, Courage to Dissent, 36.

142. Martin Luther King, Jr., "Beyond Vietnam," speech, April 4, 1967, New York, transcript. http://kingencyclopedia.stanford.edu/encyclopedia/documentsentry/doc_beyond_vietnam/ (accessed July 18, 2018). 